Chronology of the American West, by Scott C. Zeman (381 pages, January 2002), provides a capsule history of the trans-Mississippi West from migrations across the Bering Land Bridge to the contested election of Texas Gov. George W. Bush as President in 2000. Numerous sidebars on famous individuals and events alternate with plentiful blackand-white illustrations to make this volume an interesting browse. Zeman provides much Native American, Hispanic, cultural, environmental, and business history in addition to more traditional fare. $\$ 85.00$. ABC-CLIO. ISBN 1-57607-207-X.

\section{The Columbia History of Chinese Litera-} ture, edited by Victor H. Mair (1,342 pages, April 2002), offers an in-depth look at all genres and periods of Chinese poetry, prose, fiction, and drama. The 55 chapters written by more than 40 scholars cover such topics as Chinese language and script, the Thirteen Classics, the supernatural, wit and humor, poetry of the T'ang Dynasty, travel literature, 20th-century fiction, balladry, and ethnic minority literature. The emphasis is on context, trends, and themes; few extracts are provided, since these are readily available in 7 he Columbia Anthology of Traditional Chinese Literatue (1994) and other English translations. One oddity is the choice of the WadeGiles system of romanization, though Mair contends that it has been the "standard of English-language sinology for over a century." The Chinese characters for titles, terms, and authors used in the text are provided in three glossaries, along with a conversion chart from Wade-Giles to pinyin. $\$ 75.00$. Columbia University. ISBN 0-231-109849.

\section{Gaining Ground: The Origin and Evolution} of Tetrapods, by Jennifer A. Clack (369 pages, June 2002), examines when, where, and how vertebrates evolved from lobe-fin fishes and crawled out of the water onto solid ground. Clack takes into consideration anatomical changes, plant ecology, and geological events to show that the conquest of dry land was a slow process that required increased ambient oxygen levels, as well as the development of elongated limbs, larger eyes, an amniotic egg for environmental shielding, and grinding teeth for a vegetable diet. An excellent survey

George M. Eberhart is senior editor of American Libraries; e-mail: geberhart@ala.org of Devonian and Carboniferous land animals and their origins. $\$ 49.95$. Indiana University. ISBN 0253-34054-3.

Horse Behavior, by George H. Waring ( 414 pages, 2 d ed., September 2002), provides a thorough overview of the sensory capabilities, motor patterns, reproductive strategies, and social behaviors of both wild and domesticated horses. A thorough expansion of the 1983 edition, this volume includes new sections on environmental influences on horse activity patterns and other behaviors. An updated appendix that lists behavioral symptoms and probable causes should prove valuable to vererinary students, while the entire book is indispensable for horse owners and animal behaviorists. \$79.00. William Andrew Publishing, 13 Eaton Ave., Norwich, NY 13815. ISBN 0-8155-1484-0.

\section{In Another Country: Colonialism, Culture,} and the English Novel in India, by Priya Joshi (363 pages, May 2002), is an enlighrening history of reading preferences in India in the 19th and 20 th centuries. Joshi shows that instead of effectively aiding in the acculturation of colonial subjects, British novels paradoxically served to inspire an anticolonial and nationalist esprit, so much so that Indian writers from Krupa Satthianadhan to Salman Rushdie appropriated anglophone fiction to explore their own liberating insights. Of particular interest is her chapter on the circulation of fiction in Indian libraries from 1835 to 1901. \$52.50. Columbia University. ISBN 0-231-12584-4.

\section{Intellectuals in Action: The Origins of the} New Left and Radical Liberalism, 19451970, by Kevin Mattson (305 pages, June 2002), argues that the central tenets of $1960 \mathrm{~s}$ New Left political philosophy - participatory democracy, social justice, public deliberation, and the concept of the engaged intellectual--are rooted in American political thought and based more on 'Thomas Jefferson and John Dewey than on Karl Marx and counterculture. Mattson, a Generation-X history professor at Ohio University who admits it's all too easy for people his age to "roll their eyes when listening to baby boomers recount their glory days," focuses on the philosophy of C. Wright Mills, Paul Goodman, William Appleton Williams, and Amold 
Kaufman and concludes that much of what they had to say is worth reexamining in the context of America's political future. $\$ 55.00$. Penn State University. ISBN 0-271-02148-9.

The Lock, by Benita Kane Jaro (281 pages, June 2002), is the third in a trilogy of vivid historical novels set near the end of the Roman Republic. The Key (1988) focused on the poet Catullus, while The Door in the Wall (1994) revolved around the intrigues and relationships of Julius Caesar. The Lock centers more on the Roman senator Cicero and his attempts to prevent the collapse of democracy and thwart the machinations of Pompey in his bid for sole control of Rome. Written engagingly and with a clear grasp of the complexities of Roman politics, The Locks shows how the ancients cane to grips with some of the same choices and challenges that we face today. $\$ 19.95$. Bolchazy-Carducci, 1000 Brown St., Unit 101, Wauconda, IL 60084. ISBN 0-86516-535-1.

\section{The Thames Torso Murders of Victorian} London, by R. Michael Gordon ( 247 pages, July 2002), examines five gruesome murders, four in $1887-1889$ and a final one in 1902, that Gordon suspects may have been committed by Jack the Ripper or an associate. In the process, Gordon looks at how social conditions in London's East End in the 19th century might have engendered and hidden one or more serial killers. $\$ 35.00$. McFarland. ISBN 0-7864-1348-4.

\section{Time and Place in New Orleans: Past Ge- ographies in the Present Day, by Richard} Campanella (204 pages, April 2002), is a unique examination of how the Crescent City's geography has influenced its urban planning and architecture since its founding in 1717. A major factor in the city's development has been water-the swamps, river levees, drainage system, hurricanes, and canals-and the author describes the web of circumstances and patterns that water, culture, and commerce have formed in making what New Orleans is today. Profusely illustrated with modern and historic photos, its only drawback is the volume's unnecessary 13-3/8-by-10-1/2-inch size. $\$ 45.00$. Pelican. ISBN 1-56554991-0.

\section{The University of Chicago Spanish Dictio-} nary, edited by David Pharies (624 pages, 5th ed., August 2002), has been completely updated to reflect current North American Spanish usage and new words in the fields of medicine, electronics, computers, science, and technology. Another inprovement is in the consistent use of parenthetical phrases to guide word selection; for example, under the English word "sheet" are given (bedding) sábana, (of ice) capa, (of paper) boja, (of glass) lamina, and (of rain) cortina. With 80,000 entries, this concise bilingual edition can't compare with the better unabridged dictionaries (such as HarperCollins's 6th edition, 2000, which has 800,000 ), but it is easy to read, eminently portable, and contains brief summaries of Spanish and English grammar, suffixes, and irregular verbs. Phonetic pronunciation is provided for English words, but not for Spanish, which consistently matches the way a word is spelled. $\$ 27.50$. University of Chicago. ISBN 0-226-66688-3.

\section{Warfare and Armed Conflicts: A Statisti- cal Reference to Casualty and Other Fig-} ures, by Micheal Clodfelter ( 840 pages, $2 \mathrm{~d}$ ed., April 2002), presents a record of the casualties of warfare from the Italian War of Charles VIII in 1491-1498 to Chechnya and Eritrea in 2000. More than just a list of statistics, this book summarizes the short-term and long-term effects of each conflict and attempts to cut through the exaggeration and propaganda endemic to this topic. In addition to organized warfare, civil disturtbances, revolutions, prison riots, and pogroms are covered. A masterful attempt to analyze the human costs of warfare in the past 500 years. $\$ 195.00$. McFarland. ISBN 0-7864-1204-6.

\section{What It Means to Be $\mathbf{9 8 \%}$ Chimpanzee,} by Jonathan Marks (312 pages, April 2002), explores the significance of the genetic similarities between apes and humans, covering topics as diverse as the differences between racial types, the meaning of human nature, whether apes should have human rights, cloning, and the Human Genome Diversity Project. Marks writes entertainingly, often with the intent of challenging the reader's preconceptions about human beings as a species. $\$ 27.50$. University of California. ISBN 0-520-22615-1.

For interesting comparison reading, try The Dream of Eternal Life, by Mark Benecke (196 pages, April 2002), which examines the biological meaning of life and death, and the likelihood or desirability of extending the human life span to 120 or 150 years. Benecke reviews cryogenics, melatonin, organ transplants, long life secrets of the aged, live cell therapy, and the myths of human cloning. Both books put recent genetic discoveries into plain context. \$27.95. Columbia University. ISBN 0-231-11672-1. 